\title{
ASIA-PACIFIC ECONOMIC CO-OPERATION (APEC)
}

Origin and Aims. APEC was originally established in 1989 to take advantage of the interdependence among Asia-Pacific economies, by facilitating economic growth for all participants and enhancing a sense of community in the region. Begun as an informal dialogue group, APEC is the premier forum for facilitating economic growth, co-operation, trade and investment in the Asia-Pacific region. APEC has a membership of 21 economic jurisdictions, a population of over $2.5 \mathrm{bn}$. and a combined GDP of US\$19trn. accounting for $47 \%$ of world trade.

APEC is working to achieve what are referred to as the 'Bogor Goals' of free and open trade and investment in the Asia-Pacific by 2010 for developed economies and 2020 for developing economies.

Members. Australia, Brunei, Canada, Chile, China, Hong Kong, Indonesia, Japan, South Korea, Malaysia, Mexico, New Zealand, Papua New Guinea, Peru, Philippines, Russia, Singapore, Taiwan, Thailand, USA and Vietnam.

Activities. APEC works in three broad areas to meet the Bogor Goals. These three broad work areas, known as APEC's 'Three Pillars', are: Trade and Investment Liberalization - reducing and eliminating tariff and non-tariff barriers to trade and investment, and opening markets; Business Facilitation-reducing the costs of business transactions, improving access to trade information and bringing into line policy and business strategies to facilitate growth, and free and open trade; Economic and Technical Co-operation-assisting member economies build the necessary capacities to take advantage of global trade and the new economy. The 15th APEC Ministerial Meeting, held in Bangkok, Thailand in Oct. 2003, called for increased measures to stop the spread of terrorism and weapons of mass destruction.

Official language: English.

Headquarters: 35 Heng Mui Keng Terrace, Singapore 119616.

Website: http://www.apecsec.org.sg

Executive Director: Ambassador Mario Artaza (Chile).

\section{SECRETARIAT OF THE PACIFIC COMMUNITY (SPC)}

Until Feb. 1998 known as the South Pacific Commission, this is a regional intergovernmental organization founded in 1947 under an Agreement commonly referred to as the Canberra Agreement. It is funded by assessed contributions from its 27 members and by voluntary contributions from member and non-member countries, international organizations and other sources.

Members. American Samoa, Australia, Cook Islands, Fiji Islands, France, French Polynesia, Guam, Kiribati, Marshall Islands, Federated States of Micronesia, Nauru, New Caledonia, New Zealand, Niue, Northern Mariana Islands, Palau, Papua New Guinea, Pitcairn Islands, Samoa, Solomon Islands, Tokelau, Tonga, Tuvalu, UK, USA, Vanuatu, and Wallis and Futuna.

Functions. The SPC has three main areas of work: land resources, marine resources and social resources. It conducts research and provides technical assistance and training in these areas to member Pacific Island countries and territories of the Pacific.

Organization. The Conference of the Pacific Community is the governing body of the Community. Its key focus is to appoint the Director-General, to consider major national or regional policy issues and to note changes to the Financial and Staff Regulations approved by the CRGA, the Committee of Representatives of Governments and Administrations. It meets every two years. The CRGA meets once 